\title{
Postulat czwartej generacji praw człowieka w politycznym systemie międzynarodowej ochrony - próba filozoficznego uzasadnienia $z$ perspektywy personalizmu etycznego
}

\begin{abstract}
Wstęp
Koncepcję praw człowieka można ujmować poprzez pryzmat wielu nauk, na ogół czyni się to w ujęciu politologiczno-prawnym. Podejście to jednak nie wyczerpuje w pełni tego złożonego zagadnienia, które domaga się swej oceny również z pozycji filozoficzno-etycznej. Takie próby są zresztą z powodzeniem podejmowane. Także niniejsza publikacja wpisuje się w to drugie podejście, jednak jego treść nie będzie oscylować wokół ogólnego uzasadnienia idei praw człowieka (która bywa przecież podważana przez niektórych uczonych), ale tylko spróbuję uzasadnić, że postulowana przez filozofów neotomistycznych i bioetyków - personalistów tzw. czwarta generacja w rozwoju praw człowieka da się uzgodnić z podstawowymi założeniami tej koncepcji oraz z treścią ważniejszych dokumentów międzynarodowych z zakresu ochrony praw jednostki.

\section{Ważniejsze obowiązujące dokumenty z zakresu międzynarodowej ochrony praw człowieka w systemie Organizacji Narodów Zjednoczonych oraz Rady Europy}

Organizacja Narodów Zjednoczony jest międzynarodową instytucją, która położyła szczególne zasługi dla koncepcji praw człowieka. To jej Zgromadzenie Ogóle uchwaliło 10 grudnia 1948 roku słynną już Powszechna Deklarację Praw Człowieka, nazywaną przez wielu humanistów Bibliq Praw Człowieka. We wspomnianym dokumencie wyartykułowano podstawowe i niezbywalne prawa przysługujące każdej jednostce niezależnie od jakiejkolwiek różnicującej ją cechy, która mogłaby stać się podstawą dla nierównego korzystania z owych praw. Deklaracja nie posiadała co prawda mocy prawnie wiążącej lecz stała się
\end{abstract}


ona punktem wyjścia dla uchwalenia - w dniu 16 grudnia 1966 r. - wiążących już od strony prawnej tzw. Międzynarodowych Paktów Praw Człowieka, czyli Międzynarodowego Paktu Praw Gospodarczych, Społecznych i Kulturalnych oraz Międzynarodowego Paktu Praw Obywatelskich i Politycznych. Ponadto w Genewie umiejscowiono specjalny organ sądowniczy - Komitet Praw Człowieka ONZ, do którego można skierować indywidualną skargę w przypadku naruszenia obywatelskich i politycznych praw i wolności.

Oprócz wyżej przedstawionych aktów prawnych, w ramach systemu ONZ zaczęły powstawać konwencje, poświęcone ochronie konkretnego prawa ewentualnie ochronie wybranych, szczegółowych praw jednostki z określonej grupy szczególnie narażonej na dyskryminację. Spośród nich wyszczególnić trzeba: Międzynarodowa konwencję o eliminacji wszelkich form dyskryminacji rasowej (obowiązuje od 1969 r.), Konwencje w sprawie zakazu stosowania tortur oraz innego okrutnego, nieludzkiego lub poniżającego traktowania albo karania (weszła w życie w 1987 r.), Konwencję dotycząca statusu uchodźców (z 1951 r.), Konwencje w sprawie likwidacji wszelkich form dyskryminacji kobiet (z 1979 r.) oraz Konwencję o prawach dziecka (uchwaloną w 1989 r.). ${ }^{1}$

ONZ wypracowała złożony międzynarodowy system ochrony praw i wolności człowieka, powołując do ich przestrzegania odpowiednie organy i agendy. Stał się on prawno-politycznym standardem dla wszystkich państw demokratycznych oraz punktem odniesienia dla krajów, które aspirują do tego miana. Tym śladem poszły również państwa Europy Zachodniej, tworząc własną regionalną strukturę w postaci Rady Europy. Ta organizacja prawa człowieka również uznała za jeden ze swoich priorytetów.

W jej ramach 4 listopada 1950 roku przyjęto Konwencję o ochronie praw człowieka i podstawowych wolności (znanej również pod nazwą Europejskiej konwencji praw człowieka lub Konwencji Europejskiej), która z czasem została uzupełniona o trzynaście Protokołów Dodatkowych. Ta umowa międzynarodowa zapewnia ochronę praw i wolności każdemu człowiekowi z europejskiego państwa, które ją ratyfikowało. Na straży przestrzegania postanowień zawartych w Konwencji ustanowiono dwie instytucje Europejską Komisję Praw Człowieka (która obecnie po reformie systemu już nie istnieje) oraz Europejski Trybunał Praw Człowieka w Strasburgu, który orzeka w kwestii praw człowieka zawartych w Konwencji i jej protokołach dodatkowych. Konwencja określa też dopuszczalne granice, ograniczenia owych praw w sytuacjach wyjątkowych. Jednak skargi do Trybunału można kierować dopiero po wyczerpaniu środków, jakie przysługują w systemie prawnym konkretnego państwa członkowskiego. ${ }^{2}$

\footnotetext{
1 L. Кова, M. Nowicki, Historia praw człowieka, (w:) Prawa człowieka. Poradnik nauczyciela. Pod red. K. Koszewskiej, Centralny Ośrodek Doskonalenia Nauczycieli, Warszawa 2002, s. 38-43.

2 Tamże, s. 34-35.
} 
Drugim, po Konwencji Europejskiej dokumentem prawnym w systemie ochrony praw człowieka Rady Europy jest Europejska Karta Społeczna (przyjęta w 1961 r., a obowiązuje od roku 1965). Zawarto w niej katalog praw socjalnych i ekonomicznych, uzupełniając w ten sposób ich zestaw zawarty w Konwencji. ${ }^{3}$ Została ona poszerzona o protokół dodatkowy przewidujący system skarg zbiorowych.

Poza tymi dwoma dokumentami opracowanymi w systemie Rady Europy z czasem powstały także inne konwencje mające na celu zapewnić skuteczną ochronę poszczególnych praw oraz osób należących do pewnych grup szczególnie narażonych na prześladowania. ${ }^{4}$ Należy tutaj wymienić Europejska konwencję o zapobieganiu torturom oraz nieludzkiemu lub poniżajacemu traktowaniu albo karaniu (z 1987 r.) - wraz z dwoma dodatkowymi protokołami, Konwencję ramowa o ochronie mniejszości narodowych (z 1995 r.), Europejska Karte Samorzadu Terytorialnego (z 1985 r.), Konwencje o ochronie praw człowieka i godności istoty ludzkiej w kontekście zastosowań biologii i medycyny: Konwencję o Prawach Człowieka i Biomedycynie (z 1997 r.), znaną również pod nazwą Europejskiej Konwencji Bioetycznej - wraz z trzema protokołami dodatkowymi (Protokołem Dodatkowym o Zakazie Klonowania Istot Ludzkich z 1998 r.; Protokołem Dodatkowym dotyczacym Transplantacji Organów i Tkanek Pochodzenia Ludzkiego z 2002 r. oraz Protokołem dodatkowym dotyczacym Badań Biomedycznych z 2005 r.), Europejska konwencje o wykonywaniu praw dzieci (z 1996 r.) oraz Europejskie Reguly Więzienne (z 1987 r.). ${ }^{5}$

Spośród przytoczonych konwencji tej europejskiej organizacji - w kontekście przedmiotu badań niniejszego artykułu - za szczególnie interesującą należy uznać tę poświęconą problemom z obszaru biomedycyny. Jak zapisano w preambule tego dokumentu, państwa członkowskie Rady Europy oraz Wspólnoty Europejskiej mając świadomość zagrożeń dla godności ludzkiej, jakie wynikają z postępu w zakresie medycyny i biologii, postanowiły zadbać o bezpieczeństwo człowieka przed niewłaściwym wykorzystaniem ich osiągnięć. W Konwencji stwierdzono, że jej celem nadrzędnym jest chronić „godność”, „tożsamość” i „integralność” każdej istoty ludzkiej (art. 1) przekładając dobro człowieka nad interes społeczeństwa i nauki (art. 2) z zachowaniem słusznego (sprawiedliwego) dostępu do opieki zdrowotnej (art. 3). Klonowanie to następny współczesny problem z zakresu nauki i medycyny, który stanowi zagrożenie dla dobra i godności człowieka. Na to zagrożenie zwróciła uwagę Rada Europy uzupełniając

\footnotetext{
R. Rosa, Wprowadzenie, (w:) Prawa i wolności człowieka w systemie Rady Europy. Wybór i oprac. B. Bocian, M. Ożóg-Radew, Wyd. AP, Siedlce 2004, s. 11; por. R. Rosa, Bezpieczeństwo i prawa człowieka (wybrane aspekty filozoficzne i edukacyjne), (w:) Bezpieczeństwo człowieka wobec współczesnych i przyszłych wyzwań. Pod red. J. Dębowskiego, E. Jarmocha i A. W. Świderskiego, Wyd. ODN, Siedlce 2005, s. 67-76.

L. Кова, M. Nowicki, Historia praw człowieka, dz. cyt., s. 44.

5 Prawa i wolności człowieka w systemie Rady Europy, dz. cyt., s. 41-42.
} 
Konwencję o protokół dodatkowy, w którym zakazano wszelkich działań zmierzających do reprodukcyjnego sklonowania człowieka (art. 1).

Zarysowanego powyżej systemu ochrony praw człowieka Rady Europy nie należy mylić z tym obecnym w Unii Europejskiej, aczkolwiek należy podkreślić, że wszystkie kraje członkowskie UE są również członkiem Rady Europy. Z tego też powodu chciałbym ustosunkować się do problematyki ochrony praw jednostki również z unijnej perspektywy. W 2000 r. w Nicei podpisano Kartę Praw Podstawowych Unii Europejskiej - w tym dokumencie prawnym zawarto katalog praw i wolności człowieka wraz z mechanizmami ich ochrony. ${ }^{6} \mathrm{~W}$ aspekcie etyki medycznej za szczególnie ważny należy uznać artykuł 3. dokumentu, w którym gwarantuje się prawo do integralności osoby, z uwzględnieniem zgody osoby zainteresowanej na badania w dziedzinie biomedycyny, wprowadzono również zakaz dla: praktyk eugenicznych mających na celu selekcję osób; wykorzystywania ciała ludzkiego i jego części do czerpania zysków oraz reprodukcyjnego klonowania istot ludzkich. Zwłaszcza ten ostatni zapis wywołał wśród konserwatywnych etyków wiele sprzeciwów, ponieważ nie uwzględniono tam także sprzeciwu wobec klonowania ludzkich zarodków dla tzw. celów terapeutycznych.

Po ukazaniu polityczno-prawnego kontekstu międzynarodowej ochrony praw człowieka przedstawię ogólne założenia jakie przyświecają tej idei.

\section{Ogólna charakterystyka koncepcji praw człowieka}

Najprościej i najogólniej rzecz ujmując prawa człowieka zdefiniować można jako prawa, które przynależą się każdemu człowiekowi w jego kontaktach z państwem, z samej racji, że jest człowiekiem. Bez znaczenia dla ich ważności jest tutaj fakt, czy są one uznawane bądź aprobowane przez prawo państwowe, czy też przez działania innych ludzi. Przyjęcie ich bowiem w ramach konstytucyjnego porządku prawnego (czy też szerzej prawa pozytywnego) nie ma charakteru konstytutywnego, lecz jedynie deklaratywny, dlatego, że godność człowieka i jego wolność stanowi podstawę pierwotną wobec państwa i jego systemu prawnego. Co za tym następuje prawa człowieka można scharakteryzować za pomocą następujących określeń, przyjmując, że są one:?

- wrodzone (przyrodzone) - czyli istnieją niezależnie od woli władzy (prawa pozytywnego), gdyż przysługują każdej istocie ludzkiej; człowiek rodzi się

\footnotetext{
L. Кова, M. Nowicki, Historia praw człowieka, dz. cyt., s. 45-46.

M. Piechowiak, Filozofia praw człowieka. Prawa człowieka w świetle ich międzynarodowej ochrony, Towarzystwo Naukowe KUL, Lublin 1999, s. 13, 80-81; F. Compagnoni, Prawa człowieka. Geneza, historia i zaangażowanie chrześcijańskie, przeł. S. Bielański, Wyd. WAM, Kraków 2000, s. 48; W. Osiatý́sKI, Wprowadzenie do praw człowieka, (w:) źródło internetowe: http://www. hfhrpol.waw.pl/pliki/WOsiatynski_HistIFilo.pdf (10.05.2008 r.); L. КовA, M. Nowicкі, Prawa i wolności człowieka, (w:) Prawa człowieka. Podręcznik nauczyciela, dz. cyt., s. 11, 13.
} 
obdarzony tymi prawami, ponieważ stanowią one część jego człowieczeństwa, nie są więc nadawane przez państwo, które je tylko potwierdza - z tego też powodu prawa człowieka nazywane są również prawami moralnymi czy naturalnymi;

- nienabywalne - skoro są one przyrodzone, nie można ich zatem kupić, ani pozyskać za specjalne zasługi czy wyjątkową pozycję społeczną, uprawnienia te należą się bowiem każdej jednostce;

- niezbywalne - człowiek nie może zrzec się swych praw państwu, ani być ich pozbawiony przez władzę;

- nienaruszalne - państwo jest narzędziem ochrony i realizacji praw człowieka, władza nie może więc ich dowolnie naruszać i ograniczać, za wyjątkiem pewnych sytuacji, z góry przewidzianych w przepisach prawnych;

- powszechne - przynależą wszystkim ludziom bez wyjątku i w każdej sytuacji, niezależnie od pochodzenia społecznego czy narodowego, statusu materialnego, rasy, koloru skóry, płci, języka, religii, wyznawanych poglądów politycznych czy innych wyróżników;

- podstawowe - stanowią niezbędne minimum uprawnień jednostki, bez których nie mogłaby ona korzystać ze wszelkich innych praw; co ważne prawa człowieka to takie (przyrodzone, naturalne) prawa moralne, których nie trzeba uzasadniać odwołując się do jakiś innych praw, gdyż racją ich obowiązywania jest sam fakt bycia człowiekiem.

Chciałbym zwrócić uwagę jeszcze na kilka innych ważnych zagadnień charakterystycznych dla koncepcji praw człowieka.

Prawa i wolności człowieka przysługują jednostce tylko w jej kontaktach z władzą publiczną (gdyż tylko ona może je naruszyć) chroniąc ją przed jej zbyt daleko posuniętymi ingerencjami - co stanowi podstawową funkcję praw człowieka. Naturalnie niektóre z praw człowieka mogą zostać naruszone również ze strony innych obywateli, jednakże tego typu ochroną zajmuje się system prawny konkretnego kraju, np. prawa karnego czy cywilnego. Następną ważną funkcją praw człowieka jest nie tylko ochrona, ale i stworzenie przez państwo trwałych warunków umożliwiających ich realizację, np. możliwość zaskarżenia nieuprawnionej decyzji urzędników czy funkcjonariuszy publicznych do właściwego sądu (tzw. prawo do skutecznego środka odwoławczego). Pomimo faktu, że prawa człowieka zaliczane są do praw moralnych to jednak, aby w praktyce były one przestrzegane muszą być osadzone w prawie pozytywnym, i to w krajowym, ponieważ prawo międzynarodowe zapewnia jedynie ochronę pośrednią. Trzecią zaś funkcją jest ochrona przez państwo praw i wolności jednostki przed naruszeniem ich ze strony społeczeństwa. ${ }^{8}$

\footnotetext{
8 Ibidem, s. 11-12; 21; W. OsiatyŃski, Wprowadzenie do praw człowieka, dz. cyt., s. 3.
} 
Jak już wcześniej nadmieniłem za źródło praw człowieka we współczesnych koncepcjach uznaje się przyrodzoną godność człowieka. Jest ona pierwotna wobec państwa i jego systemu prawnego, który powinien ją chronić. Ochrona godności człowieka jest więc jedną z głównych funkcji praw człowieka. Jak już zauważono przyjmuje się, że godność człowieka jest wrodzona, a co za tym następuje przysługuje wszystkim istotom ludzkim bez względu na ich zasługi, nawet tym, którzy prawa te mogą łamać, np. przestępcom czy zbrodniarzom. Adwersarze koncepcji praw człowieka uważają, iż taka „równość” w godnym traktowaniu ludzi uczciwych oraz przestępców jest niesprawiedliwa i nieracjonalna. W koncepcji praw człowieka chodzi jednak o godność osobową (przynależną każdemu bez względu na czyny) a nie osobistą, gdyż ta druga jest rzeczywiście relatywna i uzależniona jest od indywidualnych zasług bądź win. Można więc ją utracić za nieetyczne postępowanie (jak np. „dobre imię”, czy ograniczenie wolności, w przypadku poważnego naruszenia norm prawnych) lub dzięki indywidualnym zasługom cieszyć się wyjątkowymi względami i szacunkiem w społeczeństwie.

Dotykamy tu ważnej kwestii jaką jest problem ograniczenia praw człowieka. W literaturze przedmiotu podkreśla się, że prawa człowieka nie są absolutne, tzn. w pewnych wyjątkowych okolicznościach można je ograniczać, pod warunkiem jednak, iż władza nie będzie tego czynić w sposób dowolny, lecz na podstawie szczegółowych procedur zapisanych w prawie oraz w sposób proporcjonalny do zagrożenia. W systemie Rady Europy na ogół wymienia się następujące racje, które uzasadniają takie postępowanie: szeroko pojmowane dobro społeczne, na które składają się: interesy bezpieczeństwa państwowego (narodowego) i publicznego, ochrona porządku i przeciwdziałanie przestępstwom (np. w czasie wojny), ochrona zdrowia i moralności obywateli oraz ochrona praw i wolności innych osób. Przykładowo zakaz kierowania pojazdami mechanicznymi dla ludzi ze słabym wzrokiem nie jest wynikiem nieuprawnionej dyskryminacji, lecz troską o bezpieczeństwo obywateli. Wolność jednostki to także jedna z podstawowych wartości, jednak i ona może być ograniczona w sytuacji uwięzienia przestępcy wyrokiem sądu. W tych wypadkach w istocie mamy do czynienia z ograniczeniem praw człowieka, a nie ich naruszeniem.

W międzynarodowych dokumentach znajdują się i takie prawa człowieka, które uznawane są za absolutne, ponieważ nie wolno ich zrelatywizować do żadnych, nawet szczególnych okoliczności. Za przykład posłużyć mogą prawa wymienione w Konwencji Europejskiej, których nie można uchylić nawet w najbardziej dramatycznych okolicznościach (np. w czasie wojny), są to prawa do:

- wolności od tortur i innego nieludzkiego albo poniżającego traktowania lub karania;

- nie bycia trzymanym w niewolnictwie lub poddaństwie;

- nie bycia karanym bez podstawy prawnej;

- nie bycia ponownie sądzonym lub karanym za ten sam czyn. ${ }^{9}$

\footnotetext{
L. Кова, M. Nowicki, Prawa i wolności człowieka, dz. cyt., s. 19-20.
} 
Do tych praw należałoby zaliczyć także fundamentalne prawo do życia (na co zwracają uwagę bioetycy - personaliści). Konwencja Europejska jednak wskazuje na sytuacje, w których może ono zostać ograniczone (art. 2.2), nie jest więc traktowane jako absolutne, nad czym ubolewają wspomniani etycy.

\section{Katalog podstawowych praw człowieka oraz ich generacje}

Katalog podstawowych praw człowieka przedstawię na przykładzie Powszechnej Deklaracji Praw Człowieka. Podstawowe prawa człowieka można byłoby uporządkować $\mathrm{w}$ kilka ${ }^{10}$ podstawowych grup:

- prawa osobiste - prawo do życia, wolności i bezpieczeństwa osobistego (art. 3); wolność od niewolnictwa lub poddaństwa (art. 4); wolność od tortur, okrutnego, nieludzkiego lub poniżającego traktowania lub karania (art. 5); wolność od arbitralnego zatrzymania, aresztowania lub wygnania (art. 9); prawo do rzetelnego i uczciwego procesu sądowego (art. 10 i 11); prawo do prywatności i rodziny (art. 12); prawo do wolności poruszania się i osiedlania oraz opuszczania jakiegokolwiek państwa i powrotu do własnego kraju (art. 13); prawo do zawarcia związku małżeńskiego i założenia rodziny (art. 16); prawo do wolności myśli, sumienia i religii (art. 18); prawo do wolności poglądów i wypowiedzi (w tym i poszukiwania, otrzymywania i przekazywania informacji oraz idei) (art. 19);

- prawa polityczne i obywatelskie ${ }^{11}$ - prawo do azylu (art. 14); prawo do posiadania obywatelstwa (art. 15); wolność do pokojowego zgromadzania się i zrzeszania się (art. 20); prawo do udziału w rządzeniu swym krajem oraz równego dostępu do służby publicznej (art. 21);

- prawa ekonomiczne (gospodarcze) - prawo do własności (art. 17); prawo do pracy, swobodnego wyboru zatrudnienia i zapewnienia dogodnych warunków pracy oraz ochrony przed bezrobociem (art. 23); prawo do nauki (nieodpłatnie, przynajmniej na poziomie podstawowym) (art. 26);

- prawa socjalne (społeczne) - prawo do ubezpieczeń społecznych (art. 22); prawo do odpoczynku, czasu wolnego i urlopu (art. 24); prawo do ochrony zdrowia i opieki społecznej (art. 25);

- prawa kulturalne - prawo do swobodnego udziału w życiu kulturalnym oraz korzystania ze sztuki, a także do współuczestnictwa w postępie naukowym i płynących z tego korzyściach; prawo do ochrony interesów autora wynikających z jego twórczości naukowej, literackiej lub artystycznej (art. 27).

\footnotetext{
10 Inni autorzy wyróżniają podział na dwa lub trzy obszary praw człowieka wyróżniając prawa osobiste; obywatelskie i polityczne (niektórzy autorzy łączą je w jedną grupę praw) oraz prawa gospodarcze (ekonomiczne), społeczne (socjalne) i kulturalne (G. Michałowska, Prawa człowieka i ich ochrona, WSziP, Warszawa 2000, s. 44-114).

11 Zagwarantowanie w konstytucjach krajowych praw obywatelskich pociąga za sobą wpisanie także obywatelskich obowiązków, takich jak podatki, obowiązek obrony państwa itp.
} 
W cytowanej Deklaracji zawarto również normy wyrażone w formie nakazów dla władzy publicznej. $\mathrm{W}$ istocie są to zasady mające na celu zabezpieczyć prawa człowieka, a szczególnie:

- wolności i równości wszystkich pod względem ich godności i praw (art. 1);

- praw i wolności każdego bez różnicy „ze względu na rasę, kolor skóry, płeć, język, religię poglądy polityczne lub jakiekolwiek inne, pochodzenie narodowe lub społeczne, majątek, urodzenie lub jakąkolwiek inną sytuację"12 (art. 2);

- prawa każdego do uznania jego osobowości prawnej (art. 6);

- równości wszystkich wobec prawa i takiej samej ochrony prawnej bez żadnej dyskryminacji (art. 7);

- prawa każdego do skutecznych procedur odwoławczych (art. 8).

Przytoczony powyżej katalog praw podstawowych nie wyczerpuje bynajmniej przedstawionego zbioru praw. Wraz z nasileniem przemian $\mathrm{w}$ sferze technicznej czy społecznej, pojawia się zapotrzebowanie na nowe prawa (np. w obszarze medycyny), które w zmienionej rzeczywistości społeczno-politycznej okazują się wręcz niezbędne dla ochrony ludzkiej godności.

W literaturze przedmiotu przyjęło się wyróżniać trzy generacje praw człowieka, z zastrzeżeniem, że trzecia generacja w rozwoju owych praw nie jest powszechnie aprobowana przez wszystkich znawców tej problematyki. Prawa osobiste i polityczne w ujęciu powyższej klasyfikacji uznane zostały za prawa pierwszej generacji, zaś prawa ekonomiczne, socjalne i kulturalne to prawa drugiej generacji. Mają one zagwarantować pewne minimum socjalne niezbędne każdemu człowiekowi do pełnego korzystania z praw osobistych i politycznych. Trzymając się tej logiki niektórzy autorzy postulują przyjęcie następne, trzeciej generacji praw, których przestrzeganie pozwoliłoby cieszyć się ludziom pełnią praw, zarówno pierwszej, jak i drugiej generacji. Miałyby to być prawa do: pokoju, rozwoju, ochrony środowiska naturalnego oraz inne, przysługujące ludom, bądź narodom w ich kontaktach ze społecznościami międzynarodowymi. ${ }^{13}$ Pojawiają się też propozycje - głównie ze strony myślicieli katolickich - uznania jeszcze czwartej generacji praw gwarantującej prawo do życia wszystkim istotom ludzkim bez jakiejkolwiek różnicy, a więc od samego poczęcia, aż po jego kres. Ten następny etap w rozwoju praw jednostki ma być odpowiedzią na dynamiczny rozwój technologii biomedycznych, które ingerują coraz głębiej w strukturę ludzkiego życia, u samych jego podstaw. ${ }^{14}$ Zagadnienie to rozwinę poniżej.

\footnotetext{
12 Cyt. za: Prawa człowieka: dokumenty międzynarodowe, przekł. i oprac. B. Gronowska, T. Jasudowicz, C. Mik, Wyd. Comer, Toruń 1996, s. 16.

13 L. Кова, M. Nowicki, Prawa i wolności człowieka, dz. cyt., s. 15.

14 F. Compagnoni, Prawa człowieka, dz. cyt., s. 265-270.
} 
Postulat czwartej generacji praw człowieka w politycznym systemie międzynarodowej ochrony...

\section{Czwarta generacja praw człowieka jako standard w systemie międzynarodowej ochrony - próba filozoficznego uzasadnienia}

W opinii moralistów i bioetyków personalistycznych dynamiczny rozwój techniki biomedycznej wymaga przyjęcia owej, czwartej generacji praw człowieka. Jej celem jest ochrona życia istot ludzkich na etapie ich rozwoju prenatalnego, po to, aby w przyszłości miały w ogóle możliwość korzystania z jakichkolwiek praw. W takim ujęciu prawo do życia jawi się jako prawo fundamentalne przysługujące każdej jednostce. Jest to prawo pierwotne, ponieważ w sytuacji, gdyby nie zostało ono zrealizowane wskutek unicestwienia życia (np. płodu) jednostka nie będzie miała w ogóle żadnej możliwości skorzystania z jakichkolwiek praw - z ontycznego faktu jej nieistnienia. Szacunek dla jednostki, niezbywalna godność człowieka, o której tak dużo wspomina się w preambułach różnych deklaracji i konwencji - w sytuacji, gdyby prawo takie nie było odpowiednio chronione - wszystko to stanie się tylko pustym retorycznym chwytem, argumentują personaliści.

Wspomniani etycy uważają ponadto, że prawo do życia domaga się potępienia wszelkich medycznych ingerencji, które ukierunkowane są na zniszczenie ludzkiego życia bez względu na fakt $\mathrm{w}$ jakiej znajduje się ono fazie. Akt taki stanowi pogwałcenie naturalnego, prawa każdego człowieka do życia chronionego w międzynarodowych dokumentach z zakresu praw człowieka, zarówno tych powstałych pod auspicjami Narodów Zjednoczonych, czy też Rady Europy, a także Unii Europejskiej ${ }^{15}$. Przypomnę, że prawo to w Powszechnej Deklaracji Praw Człowieka zapisano w artykule 3. (obok prawa do wolności i bezpieczeństwa osobistego) natomiast Międzynarodowy Pakt Praw Obywatelskich i Politycznych gwarantuje je w artykule 6. (w którym stwierdza się ponadto, że „nikt nie może być arbitralnie pozbawiony życia” ${ }^{16}$ ), a Konwencja o prawach dziecka w artykule 6. Natomiast w europejskiej Konwencji o ochronie praw człowieka i podstawowych wolności oraz w Karcie Praw Podstawowych Unii Europejskiej chronione jest ono w artykule 2.

Ponadto chrześcijańscy personaliści powołują się również na definicję „,dziecka" zapisaną w artykule 1. Konwencji o prawach dziecka. Dokument ten definiuje „dziecko” jako „każdą istotę ludzką w wieku poniżej osiemnastu lat, chyba że zgodnie z prawem odnoszącym się do dziecka uzyska ona wcześniej pełnoletność." ${ }^{17} \mathrm{~W}$ definicji tej nie zaznaczono wprost narodzin jako początku, od którego można mówić o zaistnieniu dziecka. Co ważne w preambule analizowanego aktu prawnego (ustęp 9) przytoczono cytat $z$ wcześniejszego (niewiążącego prawnie) dokumentu z tej dziedziny - tj. Deklaracji Praw Dziecka z 1959 r. - stwierdzając, że „dziecko z uwagi na swą niedojrzałość fizyczną oraz umysłową, wymaga szczególnej opieki i troski, a zwłaszcza właściwej ochrony prawnej, zarówno przed, jak i po urodzeniu”"18.

\footnotetext{
15 Faktem jest jednak, że ustawodawstwa krajów zachodnich zrzeszonych w Unii Europejskiej zalegalizowały aborcję uznając ją za prawo kobiety.

16 Cyt. za: Prawa człowieka: dokumenty międzynarodowe, dz. cyt., s. 32.

17 Cyt. za: Ibidem, s. 96.

18 Ibidem.
} 
W związku z tym „obrońcy życia” argumentują, że ich postulat objęcia uprawnieniami istot jeszcze nienarodzonych - uznając, że są one również dziećmi - nie napotyka na formalno-prawne przeszkody. Co więcej Konwencja mówi wprost o „każdej istocie ludzkiej” (every human being), biorąc więc pod uwagę empiryczny fakt $\mathrm{z}$ dziedziny biologii, że zygota, embrion czy płód jest niewątpliwie istotą ludzką (o przynależności do gatunku homo sapiens świadczy jej ludzkie DNA) - należy przyjąć, iż mamy tu do czynienia z rozwijającym się w łonie matki dzieckiem, tylko, że jeszcze nienarodzonym. Należy więc mu przyznać ochronę prawną, gwarantowaną w cytowanej wyżej Konwencji. W paragrafie 1. artykułu 6. stwierdzono bowiem, że „każde dziecko ma przyrodzone prawo do życia”. ${ }^{19}$

Wyrażenia „istota ludzka” (human being) użyto również w artykule 6. Międzynarodowego Paktu Praw Obywatelskich i Politycznych w zdaniu: „Każda istota ludzka ma przyrodzone prawo do życia”. ${ }^{21} \mathrm{~W}$ podobny sposób - uważają zwolennicy personalizmu etycznego - do tego problemu ustosunkowała się Rada Europy, która w uchwalonej Konwencji o Prawach Człowieka i Biomedycynie (tzw. Europejskiej Konwencji Bioetycznej) celowo wskazuje na potrzebę ochrony godności i tożsamości „istoty ludzkiej” (art. 1), której dobro i interes należy przedkładać nad interes społeczeństwa czy nauki (art. 2). W sprawozdaniu (nie wiążącym jednak prawnie) do tej Konwencji stwierdzono, że „powszechnie przyjętą jest zasada, zgodnie z którą godność ludzka oraz tożsamość gatunku ludzkiego powinny podlegać poszanowaniu od zapoczątkowania życia"22 (punkt 19).

Takiej wykładni nie aprobują jednak adwersarze personalizmu na gruncie bioetyki, czyli tzw. zwolennicy „prawa wyboru” (m.in. do aborcji czy eutanazji). Argumentują, że istnieje duża różnica pomiędzy „istotą ludzką” a „człowiekiem”. Zygota, a już na pewno płód niewątpliwie taką istotą (w sensie gatunkowym) jest, ale nie znaczy to, że jest człowiekiem - osobą (w sensie ontycznym), któremu przynależą się takie same prawa, jak każdemu człowiekowi. Powołują się przy tym na brzmienie artykułu 2. Powszechnej Deklaracji Praw Człowieka, w którym znalazło się sformułowanie że „Każda osoba jest uprawniona do korzystania ze wszystkich praw i wolności (...) bez jakiejkolwiek różnicy (...)"23 oraz art. 3 przypominający, że „Każda osoba ma prawo do życia, wolności i bezpieczeństwa oso-

19 Ibidem, s. 97.

${ }^{20} \mathrm{~W}$ j. angielskim zdanie to wyrażono, w taki oto sposób: Every human being has the inherent right to life.

${ }^{21}$ Cyt. za: Prawa rodziny - prawa $w$ rodzinie $w$ świetle standardów międzynarodowych: zbiór dokumentów, tłum. i oprac. T. Jasudowicz, TNOiK, Toruń 1999, s. 33.

22 Cyt. za: Europejskie standardy bioetyczne: wybór materiałów. Wstęp, tłum. i oprac. T. Jasudowicz, TNOiK, Torun 1998, s. 21 (punkt 19).

23 Cyt. za: Prawa człowieka: dokumenty międzynarodowe, dz. cyt., s. 16. W angielskiej wersji językowej zacytowany fragment brzmi: Everyone is entitled to all the rights and freedoms (...) without distinction of any kind (...). 
bistego"24; w tym samym tonie wypowiada się artykuł 2.1 Konwencji o ochronie praw człowieka i podstawowych wolności, który podkreśla, że „Prawo każdej osoby do życia chronione jest ustawą". ${ }^{25} \mathrm{~W}$ angielskich wersjach tych dokumentów użyto wyrażenia everyone, które w ich opinii odnosi się do „każdej osoby” tudzież „każdego człowieka”, zwrot ten nie mógłby być raczej użyty w stosunku do płodu czy embrionu. ${ }^{26}$ Starają się więc wskazać na istotne cechy konstytutywne „osoby” i wskazać na moment, od którego ludzki zarodek czy też płód w trakcie swojego rozwoju je nabywa. Moment ten byłby również momentem, pojawienia się bytu osobowego, któremu przysługują prawa człowieka, w tym i te fundamentalne prawo do życia. ${ }^{27}$

Jednak, jak zauważają w tym kontekście przedstawiciele etyki personalistycznej trudno w rozwoju embrionu odnaleźć jaką̧s granicę, która pozwoliłaby orzec, że teraz mamy do czynienia z człowiekiem, a nie tylko ze „zlepkiem” komórek. Jest to ciągły i niepodzielny proces, dlatego też należy orzec, że człowiekiem jest się od samego początku (czyli od zapłodnienia). $Z$ tego powodu należy uznać prawo do życia także preembrionu, ponieważ zarodek posiada już ludzką naturę, z której w przyszłości rozwiną się typowo ludzkie cechy. Nie muszą się one manifestować w postaci zaktualizowanej, wystarczy, że istnieją jako zasadnicze zdolności tkwiące w naturze

${ }^{24}$ Ibidem. W języku angielskim artykuł ten został zapisany w następujący sposób: Everyone has the right to life, liberty and the security of person.

25 Cyt. za: Prawa człowieka: dokumenty międzynarodowe, dz. cyt., s. 126. Po angielsku ustęp ten sformułowano jako: Everyone's right to life shall be protected by law.

26 Należy tutaj poczynić uwagę, że wyrażenia: „istota ludzka” - „osoba ludzka”, które pojawiają się w tekście międzynarodowych dokumentów z zakresu praw człowieka często traktowane są zamiennie, wynika to zapewne $\mathrm{z}$ różnic $\mathrm{w}$ przekładzie $\mathrm{z}$ języków oryginalnych, $\mathrm{w}$ jakich dokumenty te zostały zredagowane (mam tu na myśli j. angielski i francuski), a także $z$ faktu, że tego typu terminy są jednak nieprecyzyjne i wieloznaczne, co powoduje komplikacje w związku z ich tłumaczeniem. Na przykład art. 6 Międzynarodowego Paktu Praw Obywatelskich i Politycznych w opracowaniu (B. Gronowskiej, T. Jasudowicza i C. Miki), pt. Prawa człowieka: dokumenty międzynarodowe (dz. cyt., s. 32) został przełożony jako: „Każda osoba ludzka ma przyrodzone prawo do życia”. Sygnalizowana różnica pojawia się w tłumaczeniu tego samego artykułu w zbiorze dokumentów (przygotowanym przez T. Jasudowicza), pt. Prawa rodziny prawa $w$ rodzinie (dz. cyt., s. 33), w którym napisano: „Każda istota ludzka ma przyrodzone prawo do życia".

27 Przypomnę, iż na ogół wskazuje się tutaj (np. Peter Singer i inni utylitaryści oraz wielu naturalistów) na takie cechy, jak świadomość, czy odczuwanie bólu, których doświadczanie możliwe jest dopiero od momentu ukształtowania się centralnego układu nerwowego płodu (tzw. kryterium neurologiczne), a najpełniej dopiero po jego narodzeniu. Lewicowi politycy na ogół uważają, iż jest to przekonywujące kryterium w ustaleniu momentu obowiązywania prawa do życia, analogicznie, jak w sytuacji stwierdzenia śmierci mózgowej, kiedy uznaje się śmierć pacjenta, pomimo faktu, iż jego organizm spełnia jeszcze pewne funkcje życiowe. Kryterium neurologicznego - podobnie jak i innych kryteriów rozwojowych, np. kryterium narodzin - nie sposób jednak uznać za niepodważalne, a co za tym następuje za w pełni obiektywne ustalenie momentu „uczłowieczenia” płodu ludzkiego - z przyczyn, które już wcześniej zostały przeze mnie przedstawione. 
każdego z nas. Osobowości bowiem nie należy utożsamiać z osobą (przynależną do porządku ontycznego), ponieważ w istocie wyraża ona tylko jej właściwości. ${ }^{28}$

Personaliści nawiązują więc do klasycznej filozofii, która przyjmuje, że przejawy bytu są wtórne w stosunku do jego istnienia i jego natury. Jak to ujął Marek Piechowiak „Skoro człowiek jest osobą, jest rozumny i ma godność, niezależnie od uwarunkowań biologicznych czy społecznych, to podmiotowa racja rozumności i godności jest czymś różnym od tego, co dostępne badaniom typu przyrodniczego. Współczesny paradygmat rozumienia praw człowieka, uniezależniając godność i posiadanie praw od jakichkolwiek mierzalnych cech, zakłada pewnego typu element niematerialny w bycie ludzkim, co dobrze odpowiada rozwiązaniom proponowanym na gruncie teorii Akwinanty"29.

\section{Zakończenie}

Reasumując, personaliści są zdania, że skoro współczesna koncepcja praw człowieka wspiera się na idei przyrodzonej, niezbywalnej i nienabywalnej godności, która powszechnie przysługuje każdemu człowiekowi niezależnie od jego statusu, kondycji psychofizycznej itp. - to należy konsekwentnie w aspekcie filozoficznym uznać (jeśli chce się uniknąć sprzeczności), że przysługuje ona ludzkiemu bytowi już od poczęcia, a nie np. od czasu narodzin (w przeciwnym wypadku byłaby ona tylko nadana na zasadzie międzynarodowej umowy społecznej czyli nabyta). $\mathrm{Na}$ tej podstawie - uważają - należy przyjąć czwartą generację praw człowieka jako właściwy standard dla międzynarodowej ochrony praw jednostki.

\section{The postulate of the fourth generation of humans rights in poloticial system of international protection-attempt of philosophical reason from ethical personalism perspective}

\section{SUMMARY}

In my article I presented conception of the fourth generation worked out by Catholic ethics. Mentioned conception according to Catolic ethics should be the law's standard in international system of protection of human rights. I tried to explained a sence of this conception from the philosophy perspective linking to the basic law's acts.

Key words: human rights, philosophy, bioethics.

${ }_{28}$ M. Ciszek, Personalistyczny i utylitarystyczny model uprawiania bioetyki i biopolityki, (w:) W poszukiwaniu Prawdy, Dobra i Piękna. Pod red. R. T. Ptaszka i J. Dębowskiego, Wyd. Akademii Podlaskiej, Siedlce 2007, s. 53-56.

29 M. Piechowiak, Filozofia praw człowieka, dz. cyt., s. 353. 